\title{
Cosmopolitanism and Canadian multicultural policy: Intersection, relevance, and critique
}

\author{
Cosmopolitanismo y política multicultural \\ canadiense: intersección, relevancia y crítica
}

\section{Le Cosmopolitisme et la politique canadienne multiculturelle: Intersection, pertinence et critique}

\author{
Yvonne Hébert \\ University of Calgary, Canada
}

\begin{abstract}
Given the global scope of migration, this paper explores the re-emerging concept of cosmopolitanism for its theoretical possibilities with respect to the process of integrating into an officially multicultural country. Nine possible positionings are tentatively identified and explored, starting from global variability, global interconnectedness, and global intercommunication. The resulting theorization provides support for a cosmopolitan approach for greater understanding of the realities of multiculturalism, thus signaling the need for a renewal of this policy.
\end{abstract}

Key Words: cosmopolitanism; sociology; integration; identity; citizenship; francophone; youth.

\section{RESUMEN}

Dado el alcance global de la migración, este artículo explora el concepto re-emergente de cosmopolitismo por sus posibilidades teóricas con respecto al proceso de integración en un país oficialmente multicultural. Son tentativamente identificados y explorados nueve posibles posicionamientos, incluyendo la variabilidad, la interconexión y la intercomunicación globales. La teorización resultante sustenta un enfoque cosmopolita para una mayor comprensión de las realidades de la multiculturalidad, señalando así la necesidad de una renovación de esta política. Descriptores: cosmopolitismo; sociología; integración; identidad; ciudadanía; francófono; juventud. 


\section{RÉSUMÉ}

Étant donnée la portée globale de la migration, ce papier explore la réémergence du concept du cosmopolitisme pour ses possibilités théoriques en lien avec le processus d'intégration dans un pays officiellement multiculturel. En guise d'essai, neuf positionnements possibles sont identifiés et explorés, prenant comme acquis la variabilité globale, l'interconnexion et l'intercommunication globale. Il en résulte une théorisation cosmopolitaine qui offre un appui plus compréhensif des réalités du multiculturalisme, donnant donc signe de besoin de renouvellement de cette politique.

Mots clés: cosmopolitisme; sociologie; intégration; identité; citoyenneté; francophone; jeune.

\section{Introduction}

$\mathrm{M}$

ulticulturalism, civics, democratic education, and social studies are all circumscribed by national boundaries and national notions of citizenship as forms of national methodology, thus concomitantly neglecting globalization and its impact on the multicultural state, schooling, and young people. Yet there are many young people in schools today who have extensive knowledge of the world, be it virtual or experiential, especially those who migrate or are mobile. Many studies document such young people's eager participation in a world well beyond narrow national borders (Hoerder et al., 2005). Illustrative of this capacity, second-generation adolescents in Toronto, Winnipeg, and Calgary engage in three forms of mobility - mobility of mind, body, and boundary - all forms of mobility responding to globalization (Hébert, Wilkinson, \& Ali, 2008).

Creating an open society in Canada, inclusive of all persons, necessitates national and global systems sensitive to human rights, cultures, and expressions of both official languages, French and English. Of particular interest are French-speaking youth and adults - as migrants, immigrants, and citizens - all residents in the Canadian West who move beyond the confines of their assignation as national minority, so as to (re)define themselves in order to broaden horizons for situating themselves with ease and comfort in globalized contexts. This (re)construction of self represents broad identity tendencies nourished by the resurgence of linguistic rights and global migration, leading to the diasporic formation of an international Francophonie marked by simultaneous processes of localization and globalization. Of considerable relevance to policy formation, then, is an analysis of cosmopolitan subjectivities - that is, what it is like to live as a cosmopolitan.

Notions of integration and multicultural citizenship have been largely circumscribed by national and regional boundaries, with migrants developing complex intergroup relations and cross-cultural contact over time and place (Loewen \& Friesen, 2009). Understandings of integration, however, vary widely (Li, 2002). As evidenced in statistical analyses, public media, populist discourse, and academic research, immigrants, selected or not, are expected: (a) to match the social and economic performance of native-born 'average' Canadians; (b) to take up cultural and normative standards of Canadian society; and over time, (c) to resemble Canadians in terms of behaviour and psychological profiles, with the "persistence of cultural diversity or 
ethnicity interpreted as resistance to assimilation" (Li, 2002, pp. 49-50). In other words, integration is defined in comparison to standards based on those born in Canada. Since this subordinates immigrant groups to native-born Canadians, this underlying perspective favours the socially dominant groups at the expense of subordinate immigrants, with the dominant group holding negative stereotypes of the Other (Nagayama Hall, 2010; Sidanius \& Pratto, 1999). This allows racist considerations of non-white immigrants as being 'too many,' to be arriving faster than can be absorbed, and to be inscribed in an adaptive process exacerbated by differences in language, culture, tradition, and values (Li, 2002). Even allowing for multiculturalism and integration as dialogic processes among many, what these views reveal is that assimilative understandings of 'integration' persist and have become painfully apparent, and surprisingly so, in a country proud of its multicultural policies and laws. What these assimilative views miss, however, is that today's citizen is yesterday's immigrant, the result of previous processes of adaptation contributing to a continuously evolving sense of Canadianness.

Today, with instant global communication and remarkable ease of travel, those who have experienced migration and/or mobility, as well as the youth generation, have multiple attachments and extensive knowledge of the world, grounded in lived and virtual experiences. This must be taken into consideration in wondering what it means to be integrated in Canadian society, especially since this society is, according to its policies and laws, officially bilingual and multicultural. From such contradictions flows the need for rethinking integration as a far more complex process, necessitating new methodological conceptualizations to build a frame of reference beyond the nation to analyze new social conflicts, adaptations, dynamics, and structures (Beck, 2002a, 2002b, 2006; Beck \& Beck-Gernsheim, 2009).

The sense of being part of something bigger than one's country is pervasive among young people today who insist that they are part of a greater world, that they are global citizens, moving well beyond the confines of local ethnos, local community, local schools, and religious institutions. Young people participate eagerly in a world well beyond national borders (Hoerder et al., 2005). Second-generation adolescents of immigrant parents in schools in Toronto, Winnipeg, and Calgary engage in three forms of mobility - mobility of mind, body, and boundary - all forms responding to globalization (Hébert, Wilkinson, \& Ali, 2008). In Europe, national and transnational identities are particularly significant in geographical youth mobility, whereas family and peer networks are salient in mediating migratory movements; moreover, regional and national economic performance, as well as national and European policies, have an impact upon youth mobility patterns (Cairns, 2010). While students in Canadian schools learn to accept and respect one another, due in part to multicultural policies as enacted in curriculum and schools (Hébert \& Lee, 2006), individual human rights are not sufficient to guarantee against denigration that groups may suffer in everyday life, nor are these sufficient to thwart the vulnerabilities of people in social relationships in which they live their lives (Honneth, 1995, 2007; van Hooft, 2009, 2010).

The realities of contemporary life reveal the complexities of living within diversity 
as a normal part of co-existence, with multiple attachments and belongings. These continuing realities, shared by migrants and minorities, require new analyses and theories to support cosmopolitan connections between peoples in a highly interactive and intense globalizing world, so as to start from global variability, global interconnectedness, and global intercommunication (Beck \& Beck-Gernsheim, 2009) in order to cultivate better understandings of changing political, sociological, and psychological attributes of societal change. Thus is situated the relevance of cosmopolitan subjectivities in terms of possible positionings and practices.

While it is not the purpose of this paper to present data analyses, it is nonetheless noteworthy that two data sets, collected in Calgary, served as the bases of previous analyses with respect to a cosmopolitan sociology. One set consists of narratives elicited from graduates of Francophone high schools in minority contexts enrolled in an English-language university, ${ }^{1}$ and the Other consists of an ensemble of interviews with adults, about half of whom are recent arrivals from either side of the Sahara in Africa, participating in a study of French language immigration with respect to la Francophonie in Calgary ${ }^{2}$ (Hébert \& Wanner, 2010). These French-speaking youth and adults in the Canadian West are moving beyond the confines of their assignation as migrants and as national minority, so as to redefine themselves and to broaden horizons for situating themselves with ease and comfort in globalized contexts. This reconstruction of self is sensitive to two major identity tendencies - the resurgence of linguistic rights and global migration - as well as their contribution to a complex, diasporic formation of an international Francophonie.

Shifting identifications among this national minority are not new. In previous eras, as Francophones migrated internally from Québec and l'Acadie (the Maritimes) to other parts of Canada, there was in each instance a process of localization, resulting in cultural and technical adaptations as well as shifts of identifications while maintaining a sense of belonging to a larger collectivity (Frenette, 2004). The displacement of peoples provokes profound questionings and redefinitions of self and of belongings, especially for subjected peoples, thus producing vigorous cultures of opposition and resistance to a dominant power (Bauman, 2006). In Canada, this is observable in the discourse of resistance emanating from Québec toward the federal government, and in the discourses of victimhood from minority language groups across the country (Bernard, 1998; Castonguay, 1997, 2002a, 2002b). However, increasing sophistication, especially with the winning of school governance, is emerging to reposition French-speaking peoples within complex processes of localization and globalization (Behiels, 2004) as well as horizontal forms of governance in which the state is a partner (Cardinal, 2006), requiring a move toward greater citizen engagement (Denis, 2006, 2008; Hébert \& Wanner, 2010).

To examine such complexities, this paper addresses the question: What does it mean to be cosmopolitan? Based on a literature review, the next section on cosmopolitanism as complexity, kindness, and subjectivities explores and theorizes this concept, based on prior examination and analysis, seeking both conceptual and methodological understandings. Subsequently, a set of nine cosmopolitan subjectivities are developed 
and theoretized, followed by a critical reflection on the scope and significance of the emergence of cosmopolitan subjectivities in new populations, their future, and their relevance for the understanding of integration.

\section{Cosmopolitanism as complexity, kindness, and connection}

In its many forms and in its resurgence in times of crisis in China (as in Europe), cosmopolitanism provides much leavening for thought and consideration for possible theories and orientations to the world (Xiao, 2010). Common to all cosmopolitan views is the notion that all human beings belong to a single community, reflecting a positive moral ideal of a universal community. In other words, all humans are of equal moral standing and this community should be cultivated. The various forms of cosmopolitanism envision this ethical standard and global community in different ways, with some focusing on political institutions and others on shared moral, ethical, and or cultural expressions. The term 'cosmopolitanism' is used widely in various disciplines, especially global ethics, political science, international relations, political philosophy, sociology, cultural studies, and history. Although the literature is abundant, its review will be relatively brief, given the confines of this paper.

As a global ethical theory of the nature of human well-being, of the good life well-lived, cosmopolitanism is an ensemble of moral perspectives that overcome normative divisions between one's own people and those of others (Brown, 2009). In a country of diversity, this involves the development "of habits of coexistence: conversation in its older meaning, of living together, association" (Appiah, 2006, p. xix). For Appiah, this means to accept difference, understand it for what it is, without feeling the need to change it for something familiar to ourselves, thus arguing against some expectations of integration in Canadian contexts. This view of cosmopolitanism, as the need for kindness to strangers and as a moral commitment to our global neighbours, requires that all states respect the rights of their citizens and meets their needs. If states fail to do so, then it becomes our collective obligation and an equally fundamental cosmopolitan commitment for which we do our fair share (Appiah, 2006).

As a global political theory of a world-wide community, cosmopolitanism focuses on the demos and is concerned with legal frameworks and institutional structures adapted to globalization, in a search for a form of world governance (van Hooft, 2009). For political scholars and educators, this involves consideration of the dynamic process of international human rights crossing over into domestic law - for example, assuring the human rights of legal and illegal aliens, a step toward the integration of strangers into the full status of national citizenship (Kymlicka, 2009). From this perspective, a cosmopolitan stance would then require involvement in both local and global civil society as well as a critique of justice, power structures, and the ideological constructions of truth and belief.

As a cultural theory of global community, cosmopolitanism emphasizes the ethnos - that is, cultural diversity and intercultural dialogue - so as to bring cultural pluralism under the same umbrella (Pollock, Bhabha, Breckenridge, \& Chakrabarty, 
2000). Cultural studies of cosmopolitanism also examine processes of adaptation and awareness of rapidly changing global realities (Hannerz, 1990), as well as the means for building global community by bonding people together with shared fate, memories, solidarity, and belonging (Benhabib, 2006), thus blending in sociological perspectives. From this perspective, globalization as a social and cultural process brings a new landscape of complexity, a deeper experience of difference in which the Other is returned to a space within the self (De Lissovoy, 2010). Ethical concerns within contemporary societies must then include a basic respect for cultural differences (Kymlicka, 2001), as an essential ethical principle of the human community. A basic recognition of the transnational networks of migrants exposes an essential kindredness of persons and populations to each other, to ecological catastrophes and dwindling biodiversity, as well as the means for a genuine opening to the Other. Furthermore, a global ethical and decolonial politics and knowledge ought to be centered outside Western traditions, while reaching out to communicate with and include them (De Lissovoy, 2010).

As sociological theory, cosmopolitanism focuses on the dialectic between individual agency and social structure, addressing problems such as identity and mobility (Holton, 2009). An analysis of the affinities between the stranger in sociological thought and the cosmopolitan subject is illustrative (Marotta, 2010). Sociological and historical perspectives explore and question notions of community, mobility, identity, and co-existence as moral projects in interconnecting local and global contexts, opening up to greater feelings of togetherness and mutual bonds within radically new coordinates and relationships to place and time (Back, 2009; Beck, 2002a, 2002b, 2006; Cairns, 2010; Hall, 2008; Hébert et al., 2008; Hoerder et al., 2005, 2006; Räthzel, 2008). Reflecting upon connections between community, heterogeneity, localization, and globalization, Beck and Beck-Gernsheim (2009) argue that a cosmopolitan sociology is needed to understand the situations, impacts, divisions, contradictions, and desires of the global generations.

In explaining the meanings of cosmopolitanism, Waldron (1992) goes beyond a universal positioning as well as the philosophical debates, moving toward community complexities to find a sense of direction for the individual. He writes that the cosmopolitan is not without culture, but draws on the traces and residues of several cultural systems, of several ethical systems - and that this is key to cosmopolitanism. For him, it is this ability to situate oneself outside a particular community without letting it script or write one's life - be it a faith, tradition, religious, or cultural community and to draw selectively on discursive meaning from a variety of sources. Furthermore, Vertovec and Cohen (2002, p. 4) insist that cosmopolitanism offers a way of managing cultural and political multiplicities, simultaneously suggesting that this concept:

a) Transcends the seemingly exhausted model of the nation-state;

b) Is capable of mediating actions and ideals oriented toward both the universal and the particular, toward the global and the local; 
c) Is culturally anti-essentialist; and

d) Is capable of representing a diverse complexity of repertoires of allegiance, identity, and interest.

This positioning allows for several indicators of a cosmopolitan identity positioning. Thus, cosmopolitanism becomes not a society, but a set of interactive relations between de-nationalization and re-nationalization, between de-ethnicization and re-ethnicization, between de-localization and re-localization in society and policies (Vertovec \& Cohen, 2002, p. 81).

It is from this perspective, then, that Beck's proposals draw our interest. For him, the concept of cosmopolitanism describes a relational process that permits parallel analyses of the connections between societal changes and cosmopolitan movements, as well as resistances and blockings. Located within simultaneous localization and globalization, a cosmopolitan sociology would necessarily involve three steps: a) a critique of methodological nationalism as limitative of research and analysis; b) analyses of various transnational fractions, such as the precarious nature of work, contextualized simultaneously in glocal spaces, situations, and times; and c) a methodological cosmopolitanism that makes use of transnational constellations instead of the nationstate, so as to open up to the fundamental transformations of the current era (Beck \& Beck-Gernsheim, 2009), be it termed postmodernity, late modernity, or the second modernity.

Starting from global variability, global interconnectedness, and global intercommunication, a sociological approach means conceptualizing and analyzing ideas and data as a multiplicity of global phenomena that appear as sets of intertwined transnational constellations. Thus, in consideration of its interdisciplinary nature, conceptualizing cosmopolitan subjectivities rests upon complex understandings of all humans as being of equal moral standing, with responsibilities extended to all the peoples of the world, and commitments to express these through political action in the context of institutions with a global reach aligned toward equality, respect, and recognition (Dower, 2003; Honneth, 1995, 2007; van Hooft, 2010).

An analytic regard over the theoretical framework of the preceding section permits the development of a set of cosmopolitan practices and positionings:

- Openness toward an Other;

- Relational attachment to a locality, be it a place of origin or another;

- Recognition of the smallness of one's milieu;

- Migratory experiences, be these international, national, or regional;

- Capacity to integrate oneself in a milieu; 
- Establishment and maintenance of mutual relationships, interconnecting with other similar persons;

- Awareness of living between two entities or in multiplicity, in a larger world, with the possibility of relational subtleties and positionings;

- A moral obligation toward the Other, especially toward the less fortunate;

- Critical regards on the major contemporary questions - for example, economic and ecological crises, and hyper-consumption.

\section{Analysis: Application of the set of cosmopolitan practices and positions}

Nine practices and positions of dimensions of cosmopolitanism today are proposed below, with some theoretical elaboration for each positioning. While support for these subjectivities is provided by prior analyses of qualitative data from two research projects examining mobility and migration of Francophones in a minority situation in Calgary (Hébert, 2010a, 2010b), it is not claimed here that all participants hold all possible subject positionings proposed, nor that all are cosmopolitan.

\section{Openness toward an Other}

The movement of peoples is understood as a) a process of transcultural creativity and renewal within b) a process of integration to what already exists, as well as anxieties of new arrivals tending toward life in English rather than in French. Barriers experienced are typically linked to the lack of mastery of the English language, the nonrecognition of credentials acquired in other countries, and adaptation to living in a new milieu. In terms of cosmopolitan subjectivities, the integrative process is multifaceted and engages multiple perspectives - some delightful, yet some very difficult - as people of many sources find ways to live together, be gainfully employed, obtain recognition of their credentials, and learn English while maintaining French.

\section{Relational attachment to a locality, be it a place of origin or another}

Cosmopolitan subjectivities involve very gradual processes of developing positive associations with markers of localization, such as learning the stories of the places and learning the locations and processes of community life according to time of arrival and community development.

Integrative processes continue, from one generation to another, from one wave to another, for yesterday's immigrants are today's citizens. In doing so, the participants 
reveal the very gradual localization processes, of getting to know and attaching to local institutions, events, places, and social networks, in a process of developing positive associations with such markers of localizations.

\section{Recognition of the smallness of one's milieu}

In terms of Canadian bilingualism, the smallness may refer to the limited scope of the national linguistic policy and its practices in cities and regions other than Québec. Smallness may be external to community organizations, and may involve the lack of Francophone politicians and the perceived unfavourable position of the provincial legislature and its authorities toward the Francophonie; various difficulties accessing health services in French; and the general lack of provincial services in French, a national minority language in Alberta. Internal perceptions were noted especially with respect to the shortcomings of the Francophone leadership, a greater preoccupation with the economy than with linguistic policy, youth's diminished interest in policy, and a general absence of French-language services.

Yet at the same time, there were gradual systemic improvements with the creation of a Francophone system of education, the possibility of having a legal case heard in French, and a gradual recognition of the Calgary Francophonie. Thus, migrants and minorities alike persist, especially with respect to the restoration of French language services, the wish for a political change and various strategies of resistance.

In terms of multiculturalism, similar difficulties exist in trying to maintain a culture outside its original territories, thus leading to a blending of the original and new cultures, just as there is blending of original languages and official languages. The recognition of the limits of one's milieu inspires migrants and minorities to search for broader horizons, new ideas and ways of becoming, thus opening themselves up to other practices and positionings for greater breadth and meaning of their lives.

\section{Migratory experiences, be these international, national, or regional}

Reasons motivating migration and mobility include employment, family reasons, workplace, low level of municipal taxes, and the economic surge. Among the familial reasons are family unification, distancing family including in-laws, and the children's schooling. While these reasons are common to many individuals and groups, what is to be noted here includes the complexities of decision-making and of motivation, facilitated and influenced by global intercommunications, global interconnectedness, and global variability.

\section{Capacity to integrate oneself in a milieu}

The sentiment of adapting to a local system and demonstrating respect for local 
values so as to experience integration represents a capacity, a power to share and to get along with the local population, permitting personal development and expansion within social, cultural, and professional spheres. Accepting, first of all, to adapt oneself so as to integrate requires an acceptance and aptitude to understand different cultures and values, to feel good in strange environments by joining in, being able to function, to find oneself there - adopting habits, ways of living, and locations of this environment - and, in doing so, to find one's place. Thus, cosmopolitan subjectivities involve learning how to live comfortably with multiple attachments, how to be effective in their local integrations, and in doing so, learning how to effectively demonstrate that cosmopolitans are well grounded in glocal environments.

\section{Establishment and maintenance of mutual relationships, intercon- necting with other similar persons}

A balance between establishing and maintaining mutual relationships, interconnecting with others like oneself, is noticeable with respect to the linkages with local linguistic, cultural, and civic communities. Equally important are sentiments of belonging to one's origins and to new Canadian attachments, which can be present in several types of phenomena: 1) love and knowledge of one's origins; 2) openness, adaptation, and independence with respect to a panoply of belongings; 3) public valuing of the good image and values of one's country or region of origin; 4) resistance to negative images and discourses; 5) the will to retain cultural and linguistic elements, to take the best to weave a transcultural identification in a transparent process of creativity; and 6) possibilities to be better understood. Finally, all of this is articulated through the appreciation and interaction with cultural markers, be they material, spiritual, alimentary, symbolic, concrete, or imaginary.

\section{Awareness of living between two entities or in multiplicity, in a larger world, with possibilities of relational subtleties and positionings}

Noting the challenges and advantages of living in two official languages, developing a relational and positional agility is part of living in multiplicity, in a larger world. Migrants and minorities note the distinctiveness of each world with respect to the two official languages in Canada, creating two worlds that co-inhabit, without knowing each other well, and experiencing difficulties in balancing official and original languages whose usages are sensitive to topic, situation, interlocutor, and intention. At the same time, integration is perceived as a positive benefit of societal diversity and as favourable to intercommunity relations. International positionings allude to an opening to the exterior, with languages uniting peoples and countries in the world. To come from a Francophone country means belonging to the world-wide Francophonie, a contemporary version of what were once the French and Belgian empires, permitting the articulation of a sense of belonging to a larger world. Thus, 
in terms of an awareness of living in duality and multiplicity in a larger world, cosmopolitan subjectivities are lived in interactive relations involving de-ethnicization and re-ethnicization, de-localization and re-localization, as well as de-colonization in society and in the politics of daily life.

\section{Moral obligation toward the Other, especially the less fortunate}

Although there may not be an overt expression of a sense of moral obligation to a generalized Other, many migrants uphold obligations to family members left behind in countries of origin who depend on remittances from more fortunate family members. Assuring the security of financial transfers was of utmost importance as well as the provision of help to new arrivals and, from other perspectives, helping the host society to better understand countries of origins. Regardless of the explicitness of the colonial past, of diasporic positionings and of post-colonial and de-colonial movements, there is an awareness of repositioning of self within la Francophonie in a minority situation as a full-fledged citizen, as a bilingual citizen, meritorious of the valuing of linguistic, cultural, and socio-educational rights, with a strong awareness of the need to better understand one another in order to live well together.

\section{Critical regards on major contemporary questions}

Current examples of such questions may include the economic and ecological crises, as well as hyper-consumption in a worldwide market era. Particularly sensitive to contemporary issues, migrants and minorities see and feel the influence of a socioeconomic class system as well as links with the Other met in various venues. Here, the cosmopolitan subjectivities provide evidence of sensitivities and positionings on global issues lived locally, thus transcending the model of the nation-state, and capable of mediating actions and ideals toward the universal and the particular, toward the global and the local.

\section{Critiques and conclusion}

The concept of cosmopolitanism and especially of its subjectivities seems productive for transversal analyses of migrants' and minorities' experiences in a particular city that is, at the same time, a minority milieu with respect to French and a migratory movement whatever its provenance, be it internal or external to Canada (Hébert, 2010). Well situated in the literature, a set of nine positionings served previously as an organic analysis, given the quality and relevance of the data under consideration, and is below subjected to a critical reflection.

Let us first note the interactivity between the nine positionings proposed for the analysis. Relational and positional subtleties merge well with an awareness of living 
in duality and multiplicity. A feeling of belonging to a larger world serves to better represent and analyze the experiences and views of the participants. Moreover, the appreciation and interactions of cultural markers - be these material, spiritual, alimentary, symbolic, concrete, or imaginary - are part of the establishment and maintenance of mutual relationships, of interconnections with similar persons. It should be noted, however, that the set of positionings are permeable and that the data could possibly have been characterized differently. This represents the fluidity of the data and processes of categorization. Finally, this is a working analysis of the concept and data sets, subject to amelioration as need be.

A second point of reflection on the concept itself notes its fluidity and variability. Obviously, the travels of students and youth are not the same as the migration of people from many countries, from city to city, especially with negative experiences bringing people to migrate in the hope of a better life elsewhere. Philosophers, political scientists, and sociologists among many other scholars have considered the concept of cosmopolitanism according to their disciplinary lens and educated views. Given this diversity of opinion, it is probably wise to consider the analysis herein as exploratory, even uncertain like much in life.

A third point of reflection notes the concept's productivity - as the results of the analysis clearly demonstrate with its voyages toward the Stranger - its experiences with the Other, the fact of living as minority and as migrant, is provocative and allows for a profound reconsideration of theoretical frameworks. It is possible to recognize here that a more refined comprehension of what might be termed 'the art of living in multiplicity' is permissible for two types of participants: those who reside in a minority context, and those who migrate to new contexts. Moreover, it allows new perspectives on the recognition of 1) the importance of a socialization to place, be it scholarly or communal or parental; and 2) the necessity of a critical cosmopolitanism toward traditions and customs, one's own and those of others, raising the possibility of the relative nature of choices for a subsequent life. Given the actual context of an economic recession situated within the excesses of the capitalist financial system, it is important to consider the world-wide uncertainty, highly interdependent states, and the necessity of collaborative horizontal governance at all levels. From this globalized perspective, it is important to weave new universal motifs with local worries and issues, finely etched as detailed human experiences, needs, and hopes.

With this refinement, a fourth reflection concerns the viability of the concept, 'integration,' which is bounded by the nation-state in current thought, research analysis, policy, and folk-talk. However, what this analysis has shown, even if such as conclusion is preliminary, is that cosmopolitan subjectivities are closer to the realities of migrants' and minorities' lives than the imaginary average Canadian who drives policy decisions and hence current thinking, research analysis, and folk-talk about integration. Moreover, the distinctions between 'anglophone' and 'francophone' are 'irréaliste,' given the linguistic, socio-foundational, and cultural multiplicity of the participants, as well as new understandings of transnational constellations which rest upon and are repositioned as the 'saviour' in the current flow of possibilities. The application of this concept, however variable, is not limited to intercultural activity 
but is truly a valuable social approach to citizenship.

Given its interdisciplinary nature, conceptualizing cosmopolitan subjectivities rests upon complex understandings of equal moral standings and of civic and political commitments to all humans of the world. It goes well beyond the boundaries and bondages of the nation-state, thus providing superior sophisticated understandings of the era's key question: How shall we live together? Thus, the current limited understanding of 'integration' and of 'multicultural citizenship' as a one-way national and provincial responsibility is unlocked, and has itself the potential to unlock major policy issues.

\section{Notes}

1. Mobilités étudiantes et construction identitaire, a SSHRC-funded study, with Annie Pilote (Université Laval) as principal investigator and Marc Molgat, Stéphanie Garneau (University of Ottawa), and Yvonne Hébert (University of Calgary) as co-researchers.

2. Calgary à la lumière: Étude de la redéfinition d'une francophonie urbaine, sponsored by le Cercle de collaboration, a community group; funded by Patrimoine Canada, under an agreement with l'Association canadienne française de l'Alberta, Régionale de Calgary; and with Yvonne Hébert (University of Calgary) as Academic Director, 2008-2010. The report was launched on April 23, 2010 in Calgary.

\section{References}

Appiah, K. A. (2006). Cosmopolitanism: Ethics in a world of strangers. New York, NY: W. W. Norton \& Co.

Back, L. (2009). Research community and its moral projects. 21st Century Society, 4(2), 201-204.

Bauman, Z. (1996). From pilgrim to tourist - or a short history of identity. In S. Hall \& P. du Gay (Eds.), Questions of cultural identity (pp. 18-36). London, England: Sage.

Bauman, Z. (2006). Liquid times: Living in an age of uncertainty. Cambridge, England: Polity Press.

Beck, U. (2002a). The cosmopolitan society and its enemies. Theory, Culture \& Society, 19(12), 17-44.

Beck, U. (2002b). The cosmopolitan perspective: Sociology in the second age of modernity. In S. Vertovec \& R. Cohen (Eds.) (M. Chalmers, Trans.), Conceiving cosmopolitanism: Theory, context and practice (pp. 61-85). Oxford, England: Oxford University Press.

Beck, U. (2006). Cosmopolitan vision. Cambridge, England: Polity Press.

Beck, U. B., \& Beck-Gernsheim, E. (2009). Global generations and the trap of methodological nationalism for a cosmopolitan turn in the sociology of youth and generation. European Sociological Review, 25(1), 25-36. 
Behiels, M. D. (2004). Canada's Francophone minority communities: Constitutional renewal and the winning of school governance. Montréal and Kingston, Canada: McGill-Queen's University Press.

Beitz, C. R. (1999). Review article: International liberalism and distributive justice: A survey of recent thought. World Politics, 51(2), 269-296.

Benhabib, S. (2006). Another cosmopolitanism. With commentaries by J. Waldron, B. Honig, \& W. Kymlicka (R. Post, Ed.). The Berkeley Tanner Lectures. Oxford, England, and New York, NY: Oxford University Press.

Bernard, R. (1998). Le Canada français: entre mythe et utopia. Hearst, Canada: Le Nordir.

Brown, G. W. (2009). Grounding cosmopolitanism: From Kant to the idea of a cosmopolitan constitution. Edinburgh, Scotland: Edinburgh University Press.

Cairns, D. (Ed.) (2010). Youth on the move: European youth and geographical mobility. Weisbaden, Germany: Springer Verlag.

Castonguay, C. (1997). Évolution de l'assimilation linguistique au Québec et au Canada entre 1971 et 1991. Recherches Sociographiques, 38(3), 469-490.

Castonguay, C. (2002a). Assimilation linguistique et remplacement des générations francophones et Anglophones au Québec et au Canada. Recherches Sociographiques, 43(1), 149-182.

Castonguay, C. (2002b). Pensée magique et minorités francophones. Recherches Sociographiques, 43(1), 369-380.

Erksine, T. (2000). Embedded cosmopolitanism and the case of war: Restraint, discrimination and overlapping communities. Global Society, 14, 569-590.

De Lissovoy, N. (2010). Decolonial pedagogy and the ethics of the global. Discourse: Studies in the Cultural Politics of Education, 31(3), 279-293.

Denis, W. B. (2006). De la minorité à la citoyenneté: Rapport de la Commission sur l'inclusion dans la communauté fransaskoise. Report filed September 16, 2006, by l'Assemblée communautaire fransaskoise, Regina, Saskatchewan, Canada.

Denis, W. B. (2008). De minorité à citoyenneté: les défis de la diversité dans la communauté fransaskoise. Thèmes Canadiens (Spring), 47-49.

Dower, N. (2010). Questioning the questioning of cosmopolitanism. In S. van Hooft \& W. Vandekerckhove (Eds.), Questioning cosmopolitanism (pp. 21-35). New York, NY: Springer.

Fraser, N. (1991). A critique of actually existing democracy. In A. Calhoun (Ed.), Habermas and the public sphere (pp. 109-142). Cambridge, MA: MIT Press.

Frenette, Y. (2004). L'évolution des francophonies canadiennes: Éléments d'une problématique. In S. Langlois \& J. Létourneau (Eds.), Aspects de la nouvelle francophonie canadienne (pp. 3-18). Sainte-Foy, Canada: Presses de l'Université Laval.

Flyvbjerg, B. (2001). Making social science matter. New York, NY: Cambridge University Press.

Giddens, A. (1990). The consequences of modernity. Stanford, CT: Stanford University Press.

Giddens, A. (1991). Modernity and self-identity: Self and society in the late modern age. Stanford, CT: Stanford University Press.

Habermas, J. (1991). The structural transformation of the public sphere: An inquiry into a category of bourgeois society. Cambridge, MA: MIT Press. 
Hall, S. (2008). Armed with our inexperience: A survey of the Walworth Road. Street Signs (Autumn), 10-11.

Hannerz, U. (1990). Cosmopolitans and locals in world culture. Theory, Culture \& Society, $7(2), 237-251$.

Hansen, D. T. (2010). Cosmopolitanism and education: A view from the ground. Teachers College Record, 112(1), 1-30.

Hartmann, D., \& Gerteis, J. (2005). Dealing with diversity: Mapping multiculturalism in sociological terms. Sociological Theory, 23(2), 218-240.

Hébert, Y. (2010a). Les identités francophones cosmopolites: Une nouvelle façon de se penser. Paper and slideshow presented at the meeting, "Influence de l'inclusion, de l'exclusion et de la place sur la formation identitaire," part of the annual conference of la Société canadienne d'éducation comparée et internationale, member of the la Société canadienne pour l'étude de l'éducation (SCÉÉ), Université Concordia, Montréal, Canada, May 29-31, 2010.

Hébert, Y. (2010b). Rethinking integration as cosmopolitan subjectivities: From migrant \& minority to citizen of the world: Evidence from La Francophonie de Calgary. Paper and slideshow presented at the symposium, "Economic and ocial Integration of Migrants and Immigrants: A Comparative Approach," University of Saskatchewan, Canada, August 30-31, 2010.

Hébert, Y., \& Lee, W. J. (2006). The meaning of being Canadian: A comparison between youth of immigrant and non-immigrant origins. Canadian Journal of Education, 29(2): 497-520.

Hébert, Y., \& Wanner, R. (2010). Calgary à la lumière: Étude de la redéfinition d'une francophonie urbaine. Report filed April 23, 2010, by Cercle de collaboration \& Patrimoine Canada, Calgary. http://educ.ucalgary.ca/profiles/yvonne-hebert

Hébert, Y., Wilkinson, L., \& Ali, M. (2008). Second generation youth in Canada, their mobilities and identifications. Brock Education, 17(1), 50-70.

http://www3.ed.brocku.ca/ojs/index.php/brocked/article/viewFile/www/242

Hoerder, D., Hébert, Y., \& Schmitt, I. (Eds.) (2006). Negotiating transcultural lives: Belongings and social capital among youth in comparative perspective. Toronto, Canada: University of Toronto Press; Göttingen, Germany: V\&R unipress.

Honneth, A. (1995). The struggle for recognition: The moral grammar of social conflicts. (J. Anderson, Trans.). Cambridge, England: Polity Press.

Honneth, A. (2007). Between Aristotle and Kant: Recognition and moral obligation. In A. Honneth (Ed.), Disrespect: The normative foundations of critical theory (pp. 129-143). Cambridge, England: Polity Press.

Holton, R. J. (2009). Cosmopolitanisms: New thinking and new directions. Basingstoke, England: Palgrave Macmillan.

Isin, E. F., \& Wood, P. (1999). Citizenship and identity. London, England: Sage.

Kant, E. (1785). Grundlegung zur Metaphysik der Sitten [Grounding for the Metaphysics of Morals]. As cited by T. Erskine (2000) \& G. Kemerling (2001). http://www. http://www.philosophypages.com/hy/5i.htm

Kemerling, G. (2001). Kant: The moral order. http://www.philosophypages.com/hy/5i.htm Kymlicka, W. (2009). Multicultural odysseys: Navigating the new international politics of 
diversity. Toronto, Canada: Oxford University Press.

Levinas, E. (1998). Totality and infinity: An essay on exteriority. (A. Lingis, Trans.). Pittsburgh, PA: Duquesne University Press.

Li, P. S. (2002). Destination Canada: Immigration debates and issues. Toronto, Canada: Oxford University Press.

Loewen, R., \& Friesen, G. (2009). Immigrants in Prairie cities: Ethnic diversity in twentiethcentury Canada. Toronto, Canada: University of Toronto Press.

MacIntyre, A. (1987). The idea of an educated public. In G. Haydon (Ed.), Reason and value: The Richard Peters lectures (pp. 15-36). London, England: Institute of Education, University of London.

MacIntyre, A. (2007). After virtue (3rd ed.). Notre Dame, IN: University of Notre Dame Press.

Marotta, V. P. (2010). The cosmopolitan stranger. In S. van Hooft \& W. Vandekerckhove (Eds.), Questioning cosmopolitanism, (pp. 105-120). New York, NY: Springer.

Mbele, C. R. (2009). Essai sur le postcolonialisme en tant que code de l'inégalité. Yaoundé, Cameroon: Éditions Clé.

Nagayama Hall, G. C. (2010). Multicultural psychology (2nd ed.). Boston, MA: Prentice Hall. Peters, M. A. (2010). Editorial. Educational Philosophy and Theory, 42(1), 3-5.

Pollock, S., Bhabha, H. K., Breckenridge, C. A., \& Chakrabarty, D. (2000). Cosmopolitanisms. Culture, 12(3), 577-590.

Räthzel, N. (2008). Finding the way home: Young people's stories of gender, ethnicity, class and places in Hamburg and London. Hamburg, Germany: Vandenhoeck and Ruprecht.

Sidanius, J., \& Pratto, F. (1999). Social dominance: An intergroup theory of social hierarchy and oppression. Cambridge, England: Cambridge University Press.

Turner, B. S. (1994). Orientalism, postmodernism and globalism. London, England: Routledge.

Vandekerckhove, W., \& van Hooft, S. (2010). Introduction. In S. van Hooft \& W. Vandekerckhove (Eds.), Questioning cosmopolitanism (pp. xv-xxviii). New York, NY: Springer.

van Hooft, S. (2009). Cosmopolitanism: A philosophy for global ethics. Montréal, Canada: McGill-Queen's University Press.

van Hooft, S. (2010). Cosmopolitanism, identity and recognition. In S. van Hooft \& W. Vandekerckhove (Eds.), Questioning cosmopolitanism (pp. 7-47). New York, NY: Springer.

Vertovec, S., \& Cohen, R. (Eds.) (2002). Conceiving cosmopolitanism: Theory, context and practice. Oxford, England: University Press.

von Braun, J., \& Meinzen-Dick, R. (2009). Land grabbing by foreign investors in developing countries: Risks and opportunities. IFPRI Policy Brief, 13(April). http://www.ifpri.org/ pubs/bp/bp013.pdf, http://www.ifpri.org/pubs/bp/bp013Table01.pdf

Walzer, M. (1996). 'Spheres of Affection.' In J. Cohen (Ed.), For love of country: Debating the limits of patriotism (pp. 125-130). Boston, MA: Beacon Press.

Walzer, M. (1999). Thick and thin: Moral argument at home and abroad. Notre Dame, IN: University of Notre Dame Press.

Wanner, R. (2010). A statistical portrait of Francophones in Calgary. In Y. Hébert \& R. 
Wanner (Eds.), Calgary à la lumière: Étude de la redéfinition d'une francophonie urbaine. Report filed April 23, 2010, by Cercle de collaboration \& Patrimoine Canada, Calgary. http://educ.ucalgary.ca/profiles/yvonne-hebert

Xiao, Y. (2010). A modest genealogy of cosmopolitanism: A comparison between Europe and China. In preparation for submission to an academic journal. 